\title{
Chemical constituents of the essential oil from Syzygium cordatum (Myrtaceae)
}

\author{
Raju K. Chalannavar ${ }^{1}$, Himansu Baijnath ${ }^{1,2}$ and Bharti Odhav ${ }^{1 \star}$ \\ ${ }^{1}$ Department of Biotechnology and Food Technology, Durban University of Technology, P O Box 1334, Durban, 4000, \\ South Africa. \\ ${ }^{2}$ School of Biological and Conservation Sciences, University of KwaZulu-Natal, Westville Campus, P Bag X54001, \\ Durban, 4000, South Africa. \\ Accepted 6 December, 2010
}

\begin{abstract}
Essential oil was extracted from dried leaves of Syzygium cordatum by hydrodistillation. The components were identified by gas chromatography (GC/FID) and gas chromatography coupled with mass spectrometry (GC/MS). Sixty compounds representing $79 \%$ of the $S$. cordatum oil were identified. The main constituents were 6,10,14-trimethylpentadecane-2-one (14.4\%), 2,3-butanediol diacetate (13.3\%), n-hexadeconic acid (7.2\%), ethane, 2-chloro-1,-bis(2-chloroethoxy) (6.2\%), Isopentyloxyethyl acetate $(5.03 \%)$, methane and bis (2-chloroethoxy) $(3.8 \%)$.
\end{abstract}

Key words: Syzygium cordatum, essential oil composition, 6,10,14-trimethylpentadecane-2-one, 2, 3butanediol diacetate.

\section{INTRODUCTION}

Mankind has relied from ancient times on the usage of plant derived products for food and also for treating diseases. As much as $80 \%$ of the human population, especially from third world countries harvest plants for health care (Werka et al., 2007). From early Greece, Egypt and Rome, essential oils have been used in perfumery, as food flavorants and pharmaceuticals (Baris et al., 2006). The antimicrobial activities of essential oils are well known and with increasing interest of the applications in the food and pharmaceutical industries, there is increased interest in screening of plant extracts for active compounds (Amvam Zollo et al., 1998). Research into plant essential oils have also gained momentum due to their fumigant and contact insecticidal activities and the less stringent regulatory approval mechanisms for their exploration due to long history of use (Isman, 2006). Of late, the essential oils are being tried as potential candidates for weed control (Singh et al., 2003; Batish et al., 2004, 2007), and pest and disease management (Isman,

*Corresponding author. E-mail: odhavb@dut.ac.za. Tel: +27313735330. Fax: +27313735351.
2000; Pawar and Thaker, 2006; Abad et al., 2007). Furthermore, essential oils are easily extractable, ecofriendly in that they are biodegradable and get easily catabolized in the environment (Zygadlo and Grosso, 1995), do not persist in soil and water (Misra and Pavlostathis, 1997; Isman, 2000, 2006), possess low or no toxicity against vertebrates, fishes, birds and mammals (Enan et al., 1998, Isman, 2000; Isman and Machial, 2006; Bakkali et al., 2008), and these enables the oils to have applications even in sensitive areas such as schools, restaurants, hospitals and homes.

Looking at the importance of ecosystem services to mankind, it is worthwhile to explore environmental benefits of the natural products to mankind. Plant essential oils are obtained from non-woody parts of the plant, particularly foliage, through steam or hydrodistillation. They are complex mixtures of mainly terpenoids and oxygenated compounds that determine the characteristic aroma and odour of the donor plant. Presence of volatile monoterpenes or essential oils in the plants provides an important defense strategy to the plants, particularly against herbivorous insect pests and pathogenic fungi (Langenheim, 1994). These volatile terpenoids also play a vital role in plant-plant interactions and serve as attract- 
tants for pollinators (Tholl, 2006). They act as signaling molecules and depict evolutionary relationship with their functional roles (Theis and Lerdau, 2003).

Among various aromatic plants, plants from the Myrtaceae family are represented by over 700 species that are distributed throughout the world (Brooker and Kleinig, 2006) Eucalyptus belongs to this family and is an example of one of the most-extensively planted pulpwood species (Zobel, 1988). It consists of tall, magnificent and evergreen trees with fragrant foliage rich in oil glands and is an excellent source of commercially important eucalyptus oil that finds extensive use in pharmaceutical, perfumery and industry (Brooker and Kleinig, 2006). The essential oil from eucalyptus species are among the world's top traded oils and also, the oil extracted from Eucalyptus citriodora is one of the world's major oil in terms of trade volume (Green, 2002).

Syzygium cordatum Hochst. ex C.Krauss commonly known as waterberry also belong to the family Myrtaceae. It is widely distributed and occurs in the eastern and north eastern parts of South Africa, from KwaZulu-Natal northwards to Mozambique (Van Wyk et al., 1997). The tree is commonly found near streams, forest margins or in swampy spots. It s a medium-sized tree of up to $15 \mathrm{~m}$ in height, with a rough dark brown bark. The leaves are broad, circular with a bluish-green colour. In traditional medicinal practices, it is used by the Zulu people for respiratory ailments, including tuberculosis, and for stomach complaints and as emetics (Cunningham, 1993, Watt and Breyer-Brandwijk, 1962; Pooley, 1993) and in parts of central Africa, it is used for stomach ache, wounds and diarrhoea. Scientific studies show that the leaf extracts of $S$. cordatum contain compounds that could be effective in treating mild diabetes mellitus or glucose tolerance impairment (Musabayane et al., 2005) and the methanolic and water extracts of $S$. cordatum have been found to have antifungal activity against Candida albicans (Steenkamp et al., 2007). From the literature little is published on the chemical constituents of S. cordatum wood and bark by Candy et al., (1968) and composition of essential oil by Chisowa et al., (1998). This paper describes the composition of essential oils of leaves of $S$. cordatum.

\section{MATERIALS AND METHODS}

\section{Plant material}

Material from plants of $S$. cordatum was collected in October 2009 in the KwaZulu-Natal province of South Africa. The species was identified and a voucher specimen was deposited in the Ward Herbarium at University of KwaZulu-Natal, Westville Campus, Durban, South Africa. KwaZulu-Natal (Durban) lies in an altitude of $\sim 40 \mathrm{~m}$ on latitude $\left(29^{\circ} 48^{\prime} \mathrm{S}\right)$ and longitude $\left(30^{\circ} 56^{\prime} \mathrm{E}\right)$.

\section{Extraction of the essential oil}

The leaves of $S$. cordatum were dried in a convection oven at $25^{\circ} \mathrm{C}$ and milled (waring blender). The essential oil was extracted by slight modification of the procedure outlined by Denny (1989). $100 \mathrm{~g}$ of milled leaves were triturated in Metsabo hammer mill and hydrodistilled in a Clevenger apparatus. After $6 \mathrm{~h}$ of distillation, the essential oil was removed from the water surface. The oil was dried over anhydrous sodium sulphate. After filtration, the solvent was removed by distillation under reduced pressure in a rotary evaporator at $42^{\circ} \mathrm{C}$ and the pure oil samples were sealed and kept in a dark bottle at $4^{\circ} \mathrm{C}$ in the refrigerator for further analysis. The resulting pale yellow oil $(40 \mu \mathrm{l})$ was solubilised in $1 \mathrm{ml}$ of methyl ethyl ketone before the injection. $1 \mu \mathrm{l}$ of this solution was directly used for analysis.

\section{Gas chromatography analysis (GC/FID)}

Capillary gas chromatography was performed using a Agilent system consisting of a model 6820 gas chromatograph (Agilent, USA) and using a fused silica capillary column DB-5, $30 \mathrm{~m} \times 0.35$ $\mathrm{mm}, 0.1 \mu \mathrm{m}$ film thickness ( $\mathrm{J} \& \mathrm{~W}$ Scientific, USA). The temperature program was set from $80^{\circ} \mathrm{C}(1 \mathrm{~min})$ to $280^{\circ} \mathrm{C}(20 \mathrm{~min})$ at $15^{\circ} \mathrm{C} / \mathrm{min}$. The injection temperature was $250^{\circ} \mathrm{C}$ and the injection volume was $1.0 \mu \mathrm{l}$. The inlet pressure was $100 \mathrm{kPa}$. Nitrogen was used as a carrier gas. Sampling rate was $2 \mathrm{~Hz}(0.01 \mathrm{~min})$ and flow ionization detector temperature was set at $280^{\circ} \mathrm{C}$.

\section{Gas chromatography analysis (GC/MS)}

The GC/MS analysis of the essential oil was performed on an Agilent GC 6890 model gas chromatograph-5973N model mass spectrometer equipped with a 7683 series auto-injector (Agilent, USA). A DB-5MS column ( $30 \mathrm{~m} \times 0.25 \mathrm{~mm} \times 0.25 \mu \mathrm{m}$ film thickness) was used. Temperature program was set from $80^{\circ} \mathrm{C}(1 \mathrm{~min})$ to $280^{\circ} \mathrm{C}(20 \mathrm{~min})$. Injection volume was $1.0 \mu \mathrm{l}$ and inlet pressure was $38.5 \mathrm{kPa}$. Helium was used as carrier gas. Linear velocity $(u)$ was $31 \mathrm{~cm} / \mathrm{sec}$. Injection mode was split (75:5). MS interface temperature was $230^{\circ} \mathrm{C}$, MS mode was $\mathrm{El}$, detector voltage was $1.66 \mathrm{Kv}$, mass range was 10 to $700 \mathrm{u}$, scan speed was 2.86 scans/s and interval was $0.01 \mathrm{~min}(20 \mathrm{~Hz})$.

\section{Identification of components}

Compound identification was based on the comparison of retention indices (determined relatively to the retention times of $n$-alkanes series) using a MS library. The NIST spectrometer data bank was used to determine the percentage composition of the compounds (Adams, 2007).

\section{RESULTS}

The essential oil from $100 \mathrm{~g}$ of dried leaf powder gave a yield of $1.15 \%$ essential oil. The oil was a yellowish liquid with a strong aromatic fragrance. The chemical compound and their percentages are shown in Table 1. Sixty compounds were identified by comparison of their retention indices and the mass spectra of each GC component with those of standards and with reported data. Terpenes and derivatives predominated with the most abundant compound (14.4\%) identified as 6,10,14-trimethylpentadecane-2-one (Figure 1). This was followed by 2,3butanediol diacetate (13.3\%), n-hexadeconic acid (7.2\%), ethane, 2-chloro-1,-bis (2-chloroethoxy) (6.2\%), isopen- 
Table 1. Chemical composition of essential oil of S. cordatum.

\begin{tabular}{|c|c|c|c|}
\hline $\begin{array}{c}\text { Peak } \\
\text { number }\end{array}$ & Compound & $\mathbf{R} \mathbf{I}^{*}$ & $\begin{array}{c}\text { Area } \\
\text { peak (\%) }\end{array}$ \\
\hline 1 & Ethene, chloro- & 297 & 2.90 \\
\hline 2 & Toluene & 311 & 0.84 \\
\hline 3 & Oxirane, 2,3-dimethyl- & 347 & 0.31 \\
\hline 4 & 1,2-Epoxy-3-propyl acetate & 367 & 0.11 \\
\hline 5 & 1,3-Dioxan-4-one & 383 & 0.21 \\
\hline 6 & Ethylene maleic anhydride & 401 & 1.41 \\
\hline 7 & 2,3-Butanediol diacetate & 414 & 13.13 \\
\hline 8 & 1,1-Ethanediol, diacetate & 425 & 0.19 \\
\hline 9 & Isopentyloxyethyl acetate & 430 & 5.03 \\
\hline 10 & Glycine, N-acetyl- & 433 & 0.12 \\
\hline 11 & Hydrazine, 2-propenyl & 437 & 0.12 \\
\hline 12 & 4-Methylthiazole & 446 & 0.26 \\
\hline 13 & 2,5-Hexanedione & 455 & 0.30 \\
\hline 14 & 3-Heptanol & 464 & 0.70 \\
\hline 15 & Silane & 470 & 0.19 \\
\hline 16 & 2-Heptanone & 484 & 0.09 \\
\hline 17 & 3-Hexanol & 494 & 0.17 \\
\hline 18 & 2-Butanone, 4-(acetyloxy)- & 504 & 0.14 \\
\hline 19 & 3-Hepten-2-one, 5-methyl & 511 & 0.36 \\
\hline 20 & Triacetin & 519 & 1.07 \\
\hline 21 & 2,4-Pentanedione & 535 & 0.53 \\
\hline 22 & Propane, 1,1,2-trichloro- & 541 & 0.12 \\
\hline 23 & $\mathrm{~N}, \mathrm{~N}, \mathrm{~N}^{\prime}, \mathrm{N}^{\prime}-$ Tetraacetylethylenediamine & 548 & 1.96 \\
\hline 24 & 2,4-Dimethyl-3-pentanol acetate & 552 & 1.07 \\
\hline 25 & 2,4-Pentanedione & 555 & 0.22 \\
\hline 26 & 3-Heptanol, 3,6-dimethyl- & 559 & 1.10 \\
\hline 27 & 6,10,14-trimethylpentadecane-2-one & 574 & 14.41 \\
\hline 28 & 5-Undecanone & 604 & 0.34 \\
\hline 29 & 3-Decanone & 613 & 0.88 \\
\hline 30 & (Trimethylsilyl)diazomethane & 645 & 0.14 \\
\hline 31 & Methane, bis(2-chloroethoxy) & 654 & 3.88 \\
\hline 32 & 1,3,4-Oxadiazole & 687 & 0.32 \\
\hline 33 & Oxazole, trimethyl & 730 & 0.84 \\
\hline 34 & Ethane, 1,1-dichloro & 780 & 0.33 \\
\hline 35 & Ethane, 2-chloro-1,1-bis(2-chloroethoxy) & 838 & 6.25 \\
\hline 36 & Ethanesulfonyl chloride, 2-chloro & 848 & 0.27 \\
\hline 37 & Ledol & 866 & 0.09 \\
\hline 38 & Ethane, 1,2-bis(2-chloroethoxy)- & 881 & 0.08 \\
\hline 39 & Naphthalene, 1,2,3,4,4a,5,6,8a-octahydro(1.alpha.,4a.beta.,8a.alpha.)- & 887 & 0.68 \\
\hline 40 & Eudesma-4(14),11-diene & 903 & 0.29 \\
\hline 41 & Naphthalene, 1,2,3,4-tetrahydro-1,6-dimethyl-4-(1-methylethyl)-, (1S-cis) & 921 & 2.07 \\
\hline 42 & 2(4H)-Benzofuranone & 944 & 0.10 \\
\hline 43 & 3-Penten-2-one, 4-phenyl- & 951 & 0.13 \\
\hline 44 & trans-Z-.alpha.-Bisabolene epoxide & 977 & 0.20 \\
\hline 45 & Isoaromadendrene epoxide & 994 & 0.29 \\
\hline 46 & Nonanoic acid & 1000 & 0.10 \\
\hline 47 & Diepi-.alpha.-cedrene epoxide & 1011 & 0.11 \\
\hline 48 & 6-Isopropenyl-4,8a-dimethyl-1,2,3,5,6,7,8,8a-octahydro-naphthalen-2-ol & 1010 & 0.20 \\
\hline 49 & Azulene & 1022 & 0.09 \\
\hline
\end{tabular}


Table 1. Continue.

\begin{tabular}{|c|c|c|c|}
\hline 50 & Cedrol & 1040 & 0.14 \\
\hline 51 & Naphthalene, 1,6-dimethyl-4-(1-methylethyl)- & 1057 & 1.12 \\
\hline 52 & Isoaromadendrene epoxide & 1141 & 0.24 \\
\hline 53 & 2-Furanone & 1243 & 1.25 \\
\hline 54 & Hexadecanoic acid, methyl ester & 1392 & 2.72 \\
\hline 55 & Isophytol & 1439 & 0.11 \\
\hline 56 & n-Hexadecanoic acid & 1481 & 7.25 \\
\hline 57 & $9,12,15$-Octadecatrienoic acid, methyl ester, $(Z, Z, Z)-$ & 1890 & 0.71 \\
\hline 58 & Phytol & 1931 & 0.45 \\
\hline 59 & Octadecanoic acid, methyl ester & 1999 & 0.20 \\
\hline 60 & 1-Eicosene & 2057 & 0.31 \\
\hline
\end{tabular}

Total (\%), 79.16; ${ }^{\text {a }} \mathrm{RI}$, Retention indices relative to $n$-alkanes on DB-5 capillary column.

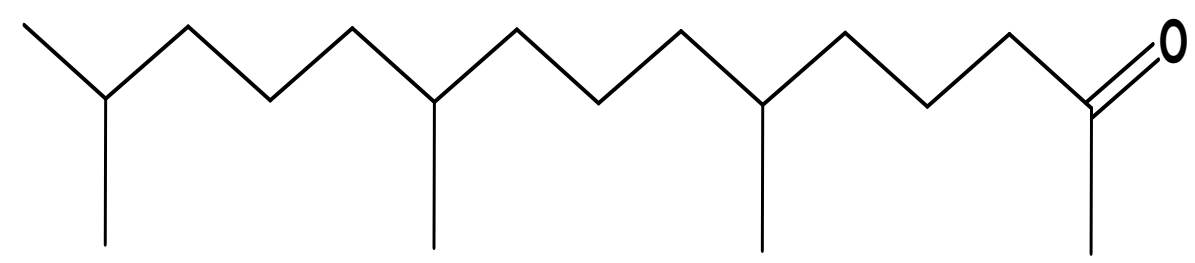

Figure 1. 6,10,14-trimethylpentadecane-2-one.

tyloxyethyl acetate $(5.03 \%)$, methane, bis (2-chloroethoxy) (3.8\%), ethene, chloro- $(2.9 \%)$, hexadecanoic acid, methyl ester (2.7\%), naphthalene, 1,2,3,4tetrahydro-1,6-dimethyl-4-(1-methylethyl)-, (1S-cis) (2\%), $\mathrm{N}, \mathrm{N}, \mathrm{N}^{\prime}, \mathrm{N}^{\prime}$-tetraacetylethylenediamine $(1.9 \%)$, ethylene maleic anhydride (1.4\%), 2-furanone (1.2\%), naphthalene, 1,6-dimethyl-4-(1-methylethyl) (1.2\%), 3-heptanol, 3,6-dimethyl- (1.1\%),2,4-dimethyl-3-pentanol acetate $(1 \%)$ and triacetin (1\%).

\section{DISCUSSION}

The yield of essential oil from $S$. cordatum is relatively higher than that reported for other industrially exploited plants such as lavender (0.8 to $1.8 \%)$, mint $(0.5$ to $1 \%)$, neroli $(0.5$ to $1 \%)$ and laurel $(0.1$ to $0.35 \%)$ (Edward et al., 1987). In another study (Leitão et al., 2008), Lippia rotundifolia illustrated a low percentage $(0.01 \%)$ of essential oil.

The major compound in the oil was 6,10,14-trimethylpentadecane-2-one, a C15 aliphatic methyl ketone. Similar long chain aliphatic methyl ketones have been reported and shown to be repellent to arthropods including blood sucking insects (Blum et al., 1996; Ndungu et al., 1995; Torr et al., 1996; Gikonyo et al., 2002; Roe, 2004). In a study by Innocent et al. (2008) on the efficacy of such compounds against Anopheles gambiae, a malaria vector, $\mathrm{C} 11-\mathrm{C} 15$ compounds were more effective than C7-C10 compounds and among the $\mathrm{C} 11-\mathrm{C} 15$ compounds, odd-carbon compounds were more effective than even-carbon compounds. In these studies, the C15 compound was found to be as effective as N, N-diethyl$\mathrm{m}$-toluamide (DEET) which is used to repel mosquitoes.

With further research, the essential oil from $S$. cordatum could prove to be an alternative to organisms that are resistant to DEET because it has $6,10,14$ trimethylpentadecane-2-one. It could also find other applications that are linked to the diversity of the other chemicals, that is, 2,3-butanedioldiacetate $(13.1 \%), \mathrm{n}$ hexadecanoic acid $(7.2 \%)$, ethane, 2-chloro-1, 1-bis (2chloroethoxy) (6.2\%), isopentyloxyethyl acetate (5\%), methane, bis (2-chloroethoxy $(3.8 \%)$, ethane, chloro$(2.9 \%)$, hexadecanoic acid $(2.7 \%)$ and naphthalene $(2.0 \%)$ which comprised more than $79 \%$ of the essential oil.

The GC-FID and GC-MS study of the essential oil from S. cordatum from KwaZulu-Natal province of South Africa led to the report of the analysis and identification of 60 compounds, representing $79.16 \%$ of the total mass. The major compound, 6,10,14-trimethylpentadecane-2-one $(14.4 \%)$ was relatively higher than that in Minuartia meyeri $(5.1 \%)$ from the family Caryophyllaceae (Nurettin et al., 2006) and close to that in Calotropis procera (15.3\%) from the family Apocynaceae (Okiei et al., 2009). As a continuation of this research, it would be necessary 
to evaluate the use of the essential oil as a repellant for insects including its role in combating malaria.

\section{REFERENCES}

Abad MJ, Ansuategui M, Bermejo P (2007). Active antifungal substances from natural sources. ARKIVOC (vii), pp. 116-145.

Adams RP (2007). Identification of Essential oil components by Gas Chromatography/Mass Spectrometry, 4th Ed. Allured Publishing Corporation. Carol Stream, Illinois.

Amvam Zollo PH, Biyiti L, Tchoumbougnana F, Menut C, Lamaty G, Bouchet $P$ (1998). Antimicrobial plants of tropical central Africa. Part XXXII. Chemical composition and antifungal activity of thirteen essential oils from aromatic plants of Cameroon. Flavour Frag. J. 13: 107-114.

Bakkali F, Averbeck S, Averbeck D, Idaomar M (2008). Biological effects of essential oils-a review. Food Chem. Toxicol. 46: 446-475.

Baris O, Güllüce M, Shahin F, özer H, Kilic H, özkan H, Sökmen M, özber $T$ (2006). Biological activities of the essential oil and methanol extract of Achillea biebersteinii (Asteraceae) Turk. J. Biol. 30: 65-73.

Batish DR, Setia N, Singh HP, Kohli RK (2004). Phytotoxicity of lemonscented eucalypt oil and its potential use as a bioherbicide. Crop Prot. 23: 1209-1214.

Batish DR, Singh HP, Setia N, Kohli RK, Kaur S, Yadav SS (2007). Alternative control of littleseed canary grass using eucalypt oil. Agron. Sust. Dev. 27: 171-177.

Blum MS, Warter SL, Traynham JG (1996). Chemical releaser of social behaviour-VI. The relation of structure of activity of ketones as releaser of alarm of Iridomyrmex pruinosus (Roger). J. Insect. Physiol. 12: 419-427.

Brooker MIH, Kleinig DA (2006). Field Guide to Eucalyptus. vol.1. South-eastern Australia, Third edition. Bloomings, Melbourne.

Candy HA, McGarry EJ, Pegel KH (1968). Constituents of Syzygium cordatum. Phytochemistry, 7: 889-890.

Chisowa EH, Sakala G, Hall DR, Farman DI (1998). Composition of the essential oil of Sygygium cordatum Hochst. Ex Krauss. J .Essent. Oil Res. 10(5): 591-592.

Cunningham AB (1993). Ethics, ethnobiological research and biodiversity. WWF-World Wide Fund for Nature (formerly World Wildlife Fund), Gland, Switzerland.

Denny EFK (1989). Hydrodistillation of oils from aromatic herbs. Perfum. Flavour, 14: 57-63.

Edward P, Claus E, Varro E, Lynn R (1987). Pharmacognosy, 6th Edition.

Enan E, Beigler M, Kende A (1998). Insecticidal action of terpenes and phenols to cockroaches: effect on octopamine receptors. In: Proceedings of the International Symposium on Plant Protection, Gent, Belgium.

Gikonyo NK, Hassanali PGN, Njagi PM, Gitu Saini RK (2002). Responses of Glossina morsitans to blends of electroantennographically active compounds in the odour of its preferred (Buffalo and Ox) and nonpreferred (Waterbuck) Hosts. J. Chem. Ecol. 29: 2331-2335.

Green C (2002). Export Development of Essential Oils and Spices by Cambodia. C.L. Green Consultancy Services, Kent, UK.

Innocent E, Gikonyo NK, Nkunya MHH (2008). Repellency property of long chain aliphatic methyl ketones against Anopheles gambiae s.s. Tanzania. J. Health Res. 10: 50-54.

Isman MB (2000). Plant essential oils for pest and disease management. Crop Prot. 19: 603-608.

Isman MB (2006). Botanical insecticides, deterrents, and repellents in modern agriculture and an increasingly regulated world. Annu. Rev. Entomol. 51: 45-66.
Isman MB, Machial CM (2006). Pesticides based on plant essential oils: from traditional practice to commercialization. In: Rai, M., Carpinella, M.C. (Eds.). Naturally Occurring Bioactive Compounds. (Eds., Rai M and Carpinella MC). Adv. Phytomed. Elsevier, 3: 29-44.

Langenheim JH (1994). Higher plant terpenoids: a phytocentric overview of their ecological roles. J. Chem. Ecol. 20: 223-1280.

Leitão SG, de Oliveira DR, Sülsen V, Martino V, Galico BarbosaY, Bizzo HR, Lopes D, Viccini LF, Salimena FRG, Peixotoe PHP, Leitão GG (2008). Analysis of the chemical composition of the essential oils extracted from Lippia lacunosa Mart. \& Schauer and Lippia rotundifolia Cham. (Verbenaceae) by gas chromatography and gas chromatography-mass spectrometry. J. Braz. Chem. Soc. 19: 13881393.

Misra G, Pavlostathis SG (1997). Biodegradation kinetics of monoterpenes in liquid and in soil-slurry system. Appl. Microbiol. Biotechnol. 47: 572-577.

Musabayane CT, Mahlalela N, Shode FO, Ojewole JAO (2005). Effects of Syzygium cordatum (Hochst.) [Myrtaceae] leaf extract on plasma glucose and hepatic glycogen in streptozotocin-induced diabetic rats. J. Ethnopharmacol. 97(3): 485-490.

Ndungu MW, Lwande W, Hassanali A, Moreka L, Chhabra SC (1995). Cleome monophylla essential oil and its constituents as tick (Rhipicephalus appendiculatus) and maize weevil (Sitophilus zeamais) repellents. Entomol. Exp. Appl. 76: 217-222.

Nurettin Y, Canan G, Osman U, Ahmet Y, Serdar U, Kamil C, Salih T (2006). Chemical and antimicrobial activities of volatile components of Minuartia meyeri. Turk. J. Chem. 30: 71-76.

Okiei W, Ogunlesi M, Ofor E, Osibote EAS (2009). Analysis of essential oil constituents in hydro-distillates of Calotropis procera (Ait.) R. Br. Res. J. Phytochemistry, 3(3): 44-53.

Pawar VC, Thaker VS (2006). In vitro efficacy of 75 essential oils against Aspergillus niger. Mycoses, 49: 316-323.

Pooley E (1993). The complete field guide to trees of Natal, Zululand and Transkei. Natal Flora Publications Trust. Natal Herbarium, Durban.

Roe RM (2004). Method of repelling insects. United States Patent Application 20040242703, Kind Code A 1.

Singh HP, Batish DR, Kohli RK (2003). Allelopathic interactions and allelochemicals:new possibilities for sustainable weed management. Crit. Rev. Plant Sci. 22: 239-311.

Steenkamp V, Fernandes AC, Van Rensburg CEJ (2007). Screening of Venda medicinal plants for antifungal activity against Candida albicans. S. Afr. J. Bot. 73: 256-258.

Theis N, Lerdau M (2003). The evolution of function in plant secondary metabolites. Int. J. Plant Sci. 164(3 Suppl.) S93-S102.

Tholl D (2006). Terpene synthases and the regulation, diversity and biological roles of terpene metabolism. Curr. Opin. Plant Biol. 9: 297304.

Torr SJ, Mangwiro TN, Hall DR (1996). Response of Glossinia pallidipes (Diptera:Glossinidae) to synthetic repellents in the field. Bull. Entomol. Res. 86: 609-616.

Van Wyk BE, Van Outshoorn B, Gericke N (1997). Medicinal Plants of South Africa. Briza Publications. South Africa Pretoria. (304 pages).

Watt JM, Breyer-Brandwijk MG (1962). The medicinal and poisonous plants of Southern and Eastern Africa. $2^{\text {nd }}$ edn. Livingstone, London.

Werka JS, Boehme AK, Setzer WN (2007). Biological activities of essential oils from Monteverde, Costa Rica. Nat. Prod. Commun. 2: 1215-1219.

Zobel B (1988). Eucalyptus in the forest industry. Tappi J. 71: 42-46.

Zygadlo JA, Grosso NR (1995). Comparative study of the antifungal activity of essential oils from aromatic plants growing wild in the central region of Argentina. Flavour Frag. J. 10: 113-118. 